\title{
Swallowable Sponge Cell Sampling Device
}

National Cancer Institute

\section{Source}

National Cancer Institute. Swallowable Sponge Cell Sampling Device. NCI Thesaurus.

Code C128141.

A minimally invasive cell sampling device comprising a sponge-like material that is compressed into a swallowable and dissolvable capsule, and a cord for retrieval. 